ISSN 1822-427X/eISSN 1822-4288

2020 Volume 15 Issue 3 (Special Issue): 157-168 https://doi.org/10.7250/bjrbe.2020-15.490

\title{
ASSESSMENT OF SKID RESISTANCE OF ROAD PAVEMENTS
}

\section{LINA ŠNEIDERAITIENE்*, DAIVA ŽILIONIENÉ \\ Dept of Roads, Vilnius Gediminas Technical University, Vilnius, Lithuania}

Received 29 May 2020; accepted 4 June 2020

\begin{abstract}
The quality of the paved road depends not only on the decisions of the road designer and the work carried out but also on the materials used. Most of the aggregates used are imported from other countries. However, the usage of domestic materials reduces the cost of the road pavement and the use of aggregates produced by a special production technology in Lithuania, i.e., dolomite aggregates instead of granite aggregates. Experimental studies were carried out on the skid resistance of the road surface. It was found that the coefficient of skid resistance met the requirements for surface dressing with dolomite aggregate, and the results were analysed with $95 \%$ probability. This coefficient partially met the requirements for asphalt concrete, while it did not meet the requirements at all for stone mastic asphalt. The surface roughness, however, met the requirements for road sections where granite aggregates were used instead of dolomite in mixes of surface dressing and asphalt concrete. The analysis was carried out considering the volume of traffic and the service life of the individual road sections. It was determined that it was suitable for a 5-year guarantee period to perform the surface dressing, wearing course of asphalt concrete and stone mastic asphalt with dolomite aggregate where part of heavy vehicles is less than $20 \%$ of traffic flow. The use of granite aggregates was justified only in the road where heavy vehicles dominated.
\end{abstract}

Keywords: aggregate, asphalt, dolomite, granite, mixture, skid resistance, surface dressing.

\footnotetext{
* Corresponding author. E-mail: lina.sneideraitiene@vgtu.lt

Lina ŠNEIDERAITIENĖ (ORCID ID 0000-0002-3477-371X)

Daiva ŽILIONIENÉ (ORCID ID 0000-0001-9647-091X)

Copyright (C) 2020 The Author(s). Published by RTU Press

This is an Open Access article distributed under the terms of the Creative Commons Attribution License (http://creativecommons.org/licenses/by/4.0/), which permits unrestricted use,

distribution, and reproduction in any medium, provided the original author and source are credited.
} 


\section{Introduction}

Aspects of innovative road construction using natural and manufactured, organic and inorganic materials focused on the competitiveness of cities, countries, and regions (Vaitkus et al., 2019, 2011; Vorobjovas et al., 2017; Wojcik, 2018). The major part of the cost of maintaining and renewing the road network consists of road paving aggregates, natural or manufactured recycled rocks, e.g., granite, diabase, gabbro, basalt, quartz diorite, dolomite, and gravel (Vaitkus \& Vorobjovas, 2015). The $80-90 \%$ of the total volume of the asphalt mix or the $90-96 \%$ of the total weight of the asphalt mix consists of fillers, sieves, and aggregates (Kogbara et al., 2016; Lodhi \& Yadav, 2016; Šneideraitienė \& Žilionienè, 2019). Aggregates are one of the main components of asphalt mixtures (Ciont et al., 2017; Gautam et al., 2018) and must comply with the Lithuanian TRA Aggregates 19 (Lithuanian Road Administration..., 2019) standard for quality (Bulevičius et al., 2013; Haritonovs et al., 2016; Kogbara et al., 2016; Lodhi \& Yadav, 2016; Šneideraitienè et al., 2016; Vaitkus et al., 2017a, 2017b). Asphalt mixtures consisting of aggregates bound with a bitumen binder are widely used as a material of surfacing. Although asphalt is a relatively cheap material, the disruption of traffic flows and the cost of replacing degraded road surfaces are significant, which leads to a demand for more durable materials (Cui et al., 2014).

\section{Literature review}

Descantes \& Hamard (2015), Haritonovs et al. (2013), Siriphun et al. (2016), Šernas et al. (2016), Vaitkus et al. (2017), Vorobjovas et al. (2017) and Wu et al. (1998) state that the surface course constitutes the top layer of the pavement and should be able to withstand high traffic volume - and environment-induced stresses without exhibiting unsatisfactory cracking and rutting to provide an even profile for the comfort of the user and at the same time possessing a texture to ensure adequate skid resistance. Depending on local conditions, functional characteristics such as skid resistance, noise reduction and durability are often required for surface courses. Kogbara et al. (2016) give an overview of friction and skid resistance measuring instruments.

In the context of road transport, the contact point is the interaction between the car wheel (tires) and the road surface, and the normal force is the wheel load. The coefficient of adhesion varies from 0 - when the road surface is covered with ice - to 1 - when the road surface is dry and clean. Adhesion is defined as the resistance to the movement of 
two surfaces at their point of contact, where the coefficient of adhesion expresses the magnitude of adhesion.

Two terms are used: "the adhesion of a tire to the road surface" ("adhesion") and "skid resistance". Both terms are frequently used and sometimes confused when it comes to the properties of the road surface (Hall et al., 2009). Pavement-tire friction is caused by a combination of two mechanisms, namely adhesion and hysteresis (Figure 1).

Adhesion is based on molecular bonds in areas of high local pressure caused by unevenness in the road surface. Hysteresis is due to loss of energy caused by the deformation of the tire rubber around the protuberances and depressions in the road surface. In addition to the mechanisms, there are two other components of rubber friction, which are of minor importance. These are frictional contributions from rubber wear and surface (or micro) hysteresis as opposed to bulk hysteresis. Tests have verified the cohesion loss component of friction due to rubber wear over the past decade (Hall et al., 2009).

In contrast to adhesion, skid resistance represents only one single contact element between the tire and the road surface. Then the skid resistance is a characteristic of the road surface that describes the effect of the pavement on adhesion. It is important to note that skid resistance is determined by performing special adhesion measurements under specific and predetermined conditions, i.e., so that all potential variables are controlled. Skid resistance is also associated with measurements

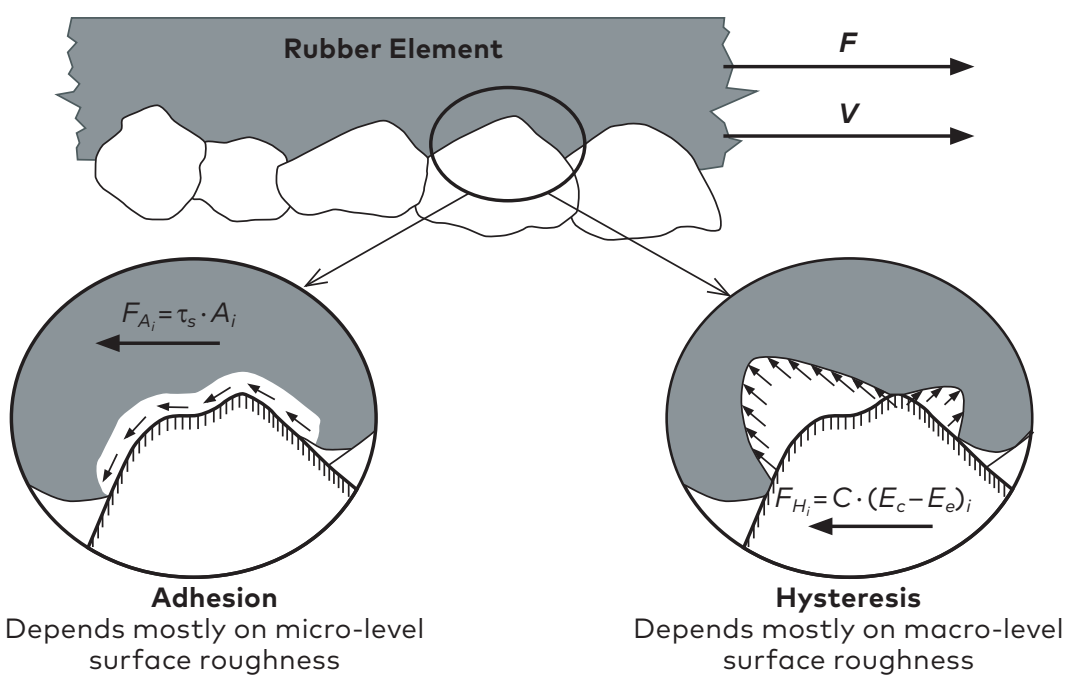

Figure 1. Fundamental mechanisms of pavement-tire friction (Hall et al., 2009) 
on wet roads when driving conditions are at their riskiest. According to Kogbara et al. (2016), the adhesion force is influenced by adhesion and hysteresis.

Micro-texture and macro-texture of the road surface are closely related to the coefficients of adhesion. Mega-texture and skid resistance are generally not considered for skid resistance (Kane et al., 2009; Scharnigg \& Schwalbe, 2010). In general, the skid resistance of the road surface is higher on dry roads, as both adhesion and hysteresis are highest under these conditions. On wet roads, the adhesion drops to zero, and the overall skid resistance is reduced (Siriphun et al., 2016; Vaitkus et al., 2017a).

As reported by Kogbara et al. (2016), Siriphun et al. (2016), Wasilewska et al. (2019), and Wu et al. (1998), in the operation of the road, it is essential to ensure adequate skid resistance of the road surface, which depends on the ability of the aggregates of the asphalt wearing course to resist the frictional forces. Continuous wheel impact over a smooth road surface reduces the skid resistance and angularity of the aggregates, resulting in a slippery road surface. The extremely slippery road surface becomes unsafe and dangerous in wet or icy conditions and when the side-friction between the wheel and the road surface is reduced to a minimum. The road becomes unsafe and dangerous as well (Noyce et al., 2005; Räisänen et al., 2003; Santucci \& Engineer, 2013; Vaiana et al., 2012; Wasilewska et al., 2019). Therefore, both characteristics - friction and texture - of the road surface are essential aspects of traffic safety.

The analysis of the scientific literature raises the hypothesis "Is it possible to use a dolomite aggregate, i.e. locally mined as well as locally produced aggregate, in mixtures for the road surface and a wearing course due to the adherence to the skid resistance value".

\section{Plan of experiment and methodology}

A plan of the experiment was made to prove the hypothesis (Figure 2).

As stated in TRA Asphalt 08 Technical Specifications for Road Asphalt Mixtures (Lithuanian Road Administration..., 2008), the minimum (limit)

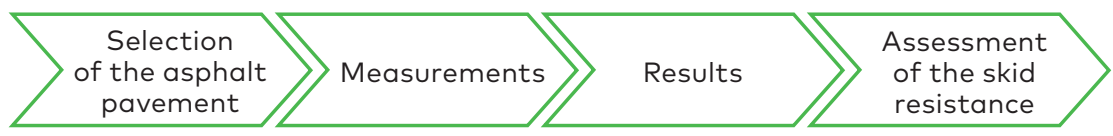

Figure 2. Plan of experiment and methodology 
value of the coefficient of skid resistance of the road surface at the time of paving the road is not less than 0.50 - on main roads and 0.45 - on national and regional roads in Lithuania. Different types, i.e., surface dressing (on the road surface), asphalt concrete and stone mastic asphalt (in wearing course) with dolomite and granite aggregates in surfacing mixes and under different operating periods (from 3 to 7 years) were selected for the investigation in the selected road sections. The operating time for all selected road sections was more than one year. Accordingly, the skid resistance values were accepted to establish a fact, not for comparison.

During the experimental investigation, the skid resistance of the road surface was determined by CEN/TS 15901-14:2016 Road and Airfield Surface Characteristics - Part 14: Procedure for Determining the Skid Resistance of a Pavement Surface Using a Device with Longitudinal Controlled Slip (LFCN): ViaFriction (Road Analyser and Recorder of ViaTech $A S)$ (Figure 3).

The measurements were carried out with a fixed coefficient of skid resistance of $18 \%$ and a constant operating speed of $60 \mathrm{~km} / \mathrm{h}$. Besides, the air temperature, humidity, and Global Positioning System (GPS) coordinates were determined. The measurements were carried out on the right side of the road, and the trajectory left wheel in the direction of increasing kilometres. The measurements were carried out in July when the adhesion value of the vehicle wheel is lowest with the road surface. The measurements were carried out on sections with surface dressing, asphalt concrete and stone mastic asphalt, where dolomite or granite aggregates were used in the paved asphalt concrete mixtures.

\section{Analysis of the results of experimental research}

Table 1 presents the number of skid resistance measurements on road sections with different aggregates. Also, required for the analysis, the traffic volume data were taken from the LAKIS (Lithuanian Automobile Road Information System) database.

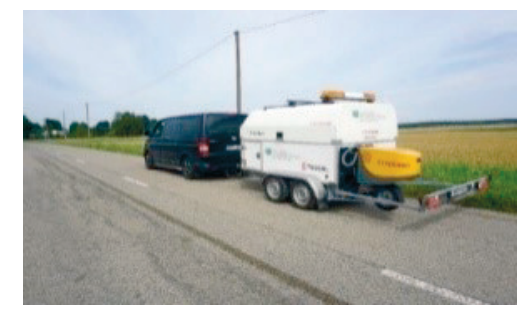

Figure 3. Road Analyser and Recorder of ViaTech AS 


\begin{tabular}{llc}
\hline \multicolumn{1}{c}{ Type of surfacing } & Aggregate & Number of measurements \\
\hline \multirow{2}{*}{ Surface dressing } & dolomite & 932 \\
& granite & 379 \\
\multirow{2}{*}{ Asphalt concrete } & dolomite & 623 \\
& granite & 498 \\
Stone mastic asphalt & dolomite & 2029 \\
& granite & 1572 \\
\hline
\end{tabular}

The assessment of skid resistance of surface dressing, asphalt concrete, and stone mastic asphalt with dolomite and granite aggregates was carried out based on the plan of experiment and methodology. The measurement results were analysed using statistical methods and with 95\% probability (Figures $4-6$ ).

Figure 4 presents research results on the roads with surface dressing. It was found that on the national road No. 194 with dolomite aggregate in surface dressing $10 \%$ of traffic volume was represented by heavy vehicles. The service life of the road was four years. As the coefficient of skid resistance met the requirement for national roads $(0.45)$ almost by one and a half times, it was concluded that the use of dolomite aggregate in surface dressing proved to be justified.

Heavy vehicles, dolomite aggregate

Cars, dolomite aggregate
Heavy vehicles, granite aggregate

Cars, granite aggregate

- Coefficient of skid resistance in 2018

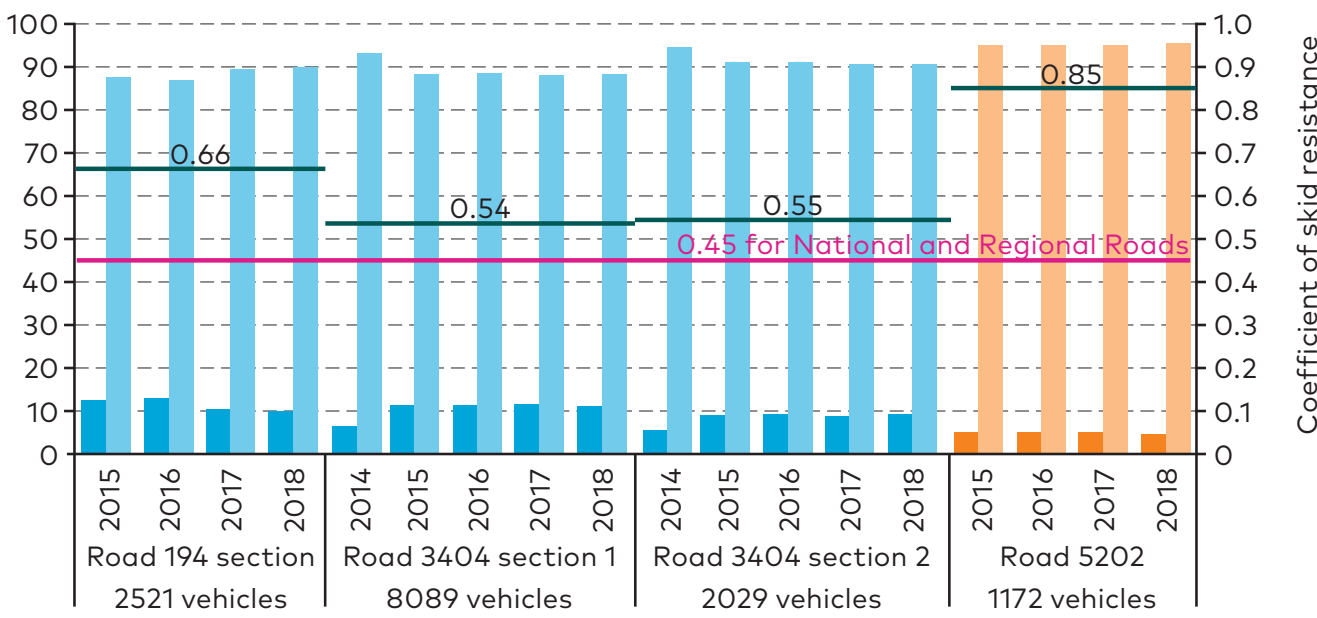

PAVEMENT - SURFACE DRESSING

Figure 4. Research results on surface dressing 
The traffic volume on the 2nd section of regional road No. 3404 was $27 \%$ lower than on the 1 st section of this road, but on both sections, about $10 \%$ of traffic volume was represented by heavy vehicles. The service life of regional road No. 3404 corresponded to a 5-year guarantee period, and the coefficient of skid resistance determined on both sections of this road met the requirements for the regional roads (0.45). It was, therefore, concluded that the use of dolomite aggregates for surface dressing proved to be justified.

The traffic volume on the 1st section of regional road No. 3404 was $42 \%$ lower and $47 \%$ higher than on the 2 nd section of regional road No. 3404 , but $6 \%$ of traffic volume was represented by heavy vehicles on regional road No. 5202 with granite aggregate in surface dressing. As the road had a service life of four years, a 5-year guarantee period did not expire. As a result, the coefficient of skid resistance almost doubled, and it was concluded that the use of granite aggregates in the surface dressing of this road was overplus and did not work.

Figure 5 presents the research results on the roads with a wearing course of asphalt concrete. Main road No. A4 with dolomite aggregate showed that $6 \%$ of traffic volume was represented by heavy vehicles, and the service life of the road was more than a 5 -year guarantee period (6 years). As the coefficient of skid resistance met the requirements of such roads almost one and a half time, it was concluded that the use of dolomite aggregate in the wearing course of asphalt concrete was justified.

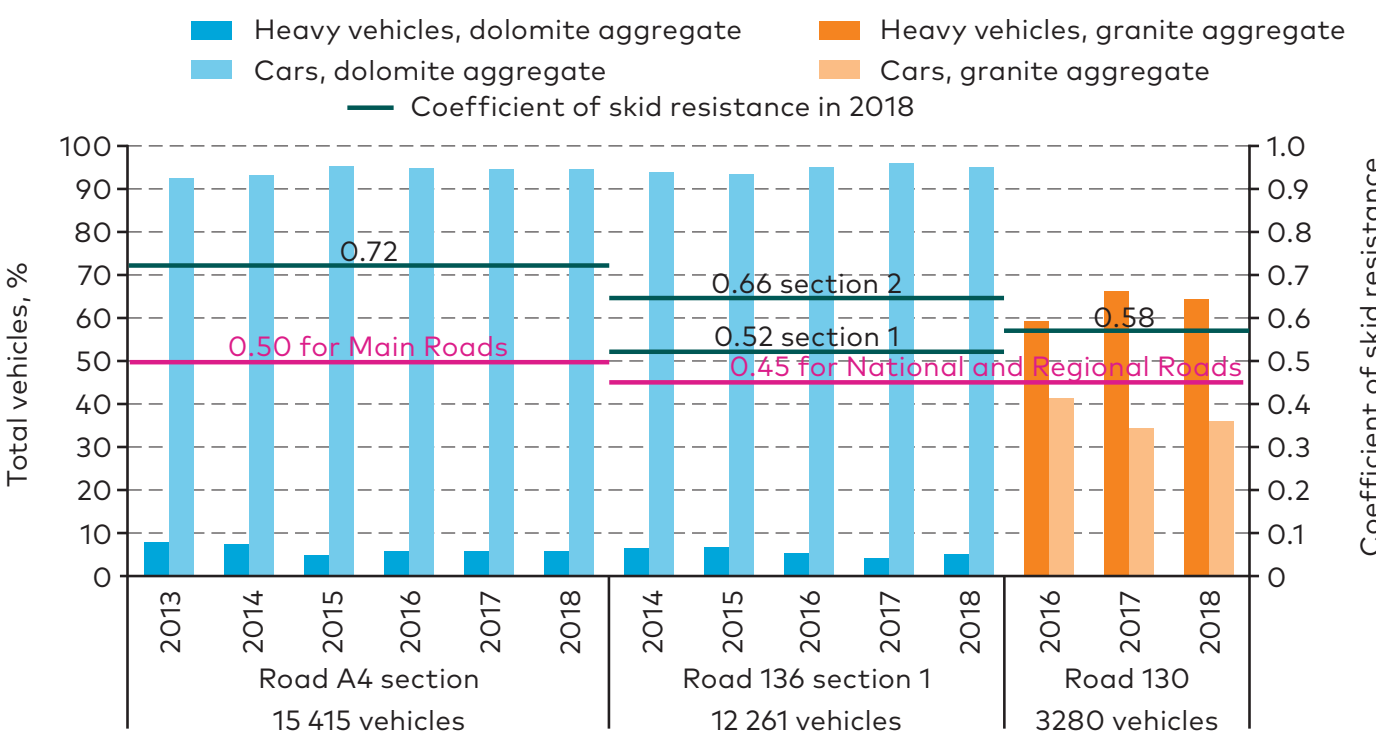

PAVEMENT - ASPHALT CONCRETE

Figure 5. Research results on asphalt concrete 
On national road No. 136, the volume of heavy vehicles was 5\% in traffic flow and the operating time of this road corresponded to a 5-year guarantee period. As the coefficient of skid resistance was $16 \%$ higher than the required level in the 1 st section and $47 \%$ in the 2 nd section, it was concluded that the use of dolomite aggregate in the wearing course of asphalt concrete was justified.

Also, the volume of heavy vehicles was $60 \%$ in traffic flow on national road No. 130 and this road was used for only three years (2 years to the end of a 5-year guarantee period). It was found that the coefficient of skid resistance was 30\% higher than required. Thus, it was concluded that the use of granite aggregates in the wearing course of asphalt concrete was justified and the road should be used until the end of the guarantee period. However, after the end of a 5-year guarantee period, additional measurements of the coefficient of skid resistance should be carried out.

Figure 6 shows the research results on roads with a wearing course of stone mastic asphalt. On the main road No. A3 with dolomite aggregate, the heavy vehicles accounted for $20 \%$ of the traffic volume, and the road was used for longer than a 5-year guarantee period (6 years). As the coefficient of skid resistance was 14\% lower than that required for such roads, it was concluded that the use of dolomite aggregate in the wearing course of stone mastic asphalt was not justified.

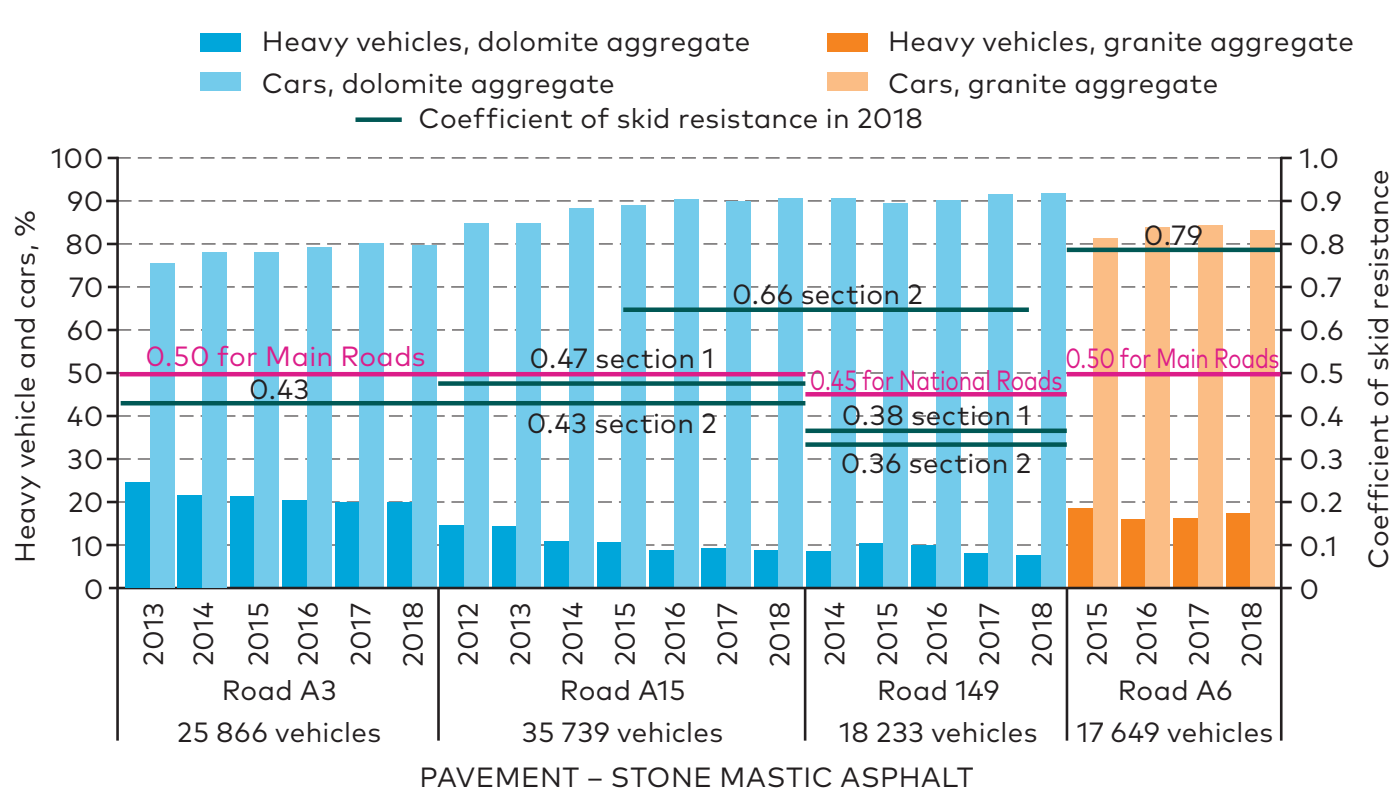

Figure 6. Research results on stone mastic asphalt 
However, the situation was quite different on the main road No. A15, where traffic of heavy vehicles accounted for $12 \%$ of the traffic flow and the road had a guaranty period of more than five years, i.e., seven years. The coefficient of skid resistance did not meet the requirements, as in the case of the main road No. A3, so it could not be concluded that the use of dolomite aggregates was successful or not. It is therefore proposed that after a 5-year guarantee period roads with a wearing course of stone asphalt mastic with dolomite aggregates were used. The traffic volume of heavy vehicles was less than $20 \%$, annual tests of the coefficient of skid resistance should be carried out to guarantee road roughness, which is essential for road safety.

On the national road No. 149 with dolomite aggregate, it was found that heavy vehicles accounted for $10 \%$ of traffic flow and the road was in operation until the end of a 5-year guarantee period. As the coefficient of adhesion on both road sections did not meet the requirement for paving such roads, it was concluded that the use of dolomite aggregate in mastic was not justified.

On the main road No. A6, a wearing course with granite aggregate was paved. Heavy vehicles accounted for $17 \%$ of the traffic flow on this road, and this road was operated for four years, i.e., the guaranty period of 5 years had not expired. The determined coefficient of skid resistance was almost one and a half times higher than required. It was concluded that the use of granite aggregate in a wearing course of stone mastic asphalt was overplus. It was possible to install a wearing course of asphalt concrete with dolomite aggregates on this road because the percentage of heavy vehicles in the traffic flow and the traffic flow was lower (less than 20\%) compared to the main road No. A3 on which a wearing course of asphalt concrete with dolomite aggregates was paved.

\section{Conclusions}

The hypothesis "Is it possible to use a dolomite aggregate, i.e., locally mined as well as locally produced aggregate, in mixtures for the road surface and a wearing course of surfacing due to the adherence to the skid resistance value" was proven and following conclusions were made.

1. The measurement results were analysed using statistical methods and with $95 \%$ probability.

2. The use of dolomite aggregates in the surface dressing was justified in sections of national and regional roads; however, the use of granite aggregate was overplus in sections of regional roads with the surface dressing. 
3. The use of dolomite and granite aggregates in a wearing course of asphalt concrete was justified on the sections of main and national roads, but not justified in a wearing course of stone asphalt mastic on the same significant roads.

4. The use of dolomite aggregates was justified when the heavy vehicles accounted for less than $20 \%$ of traffic volume during a 5-year guarantee period on roads with surface dressing and asphalt concrete pavement.

5. The use of granite aggregates was justified on the section of the main road where $60 \%$ of traffic volume was represented by heavy vehicles.

6. The use of granite aggregate becomes overplus and uneconomical in all types of tested pavements with $20 \%$ (or even less) of heavy vehicles in traffic flow.

7. Therefore, more research and economic calculations are needed to make more extensive use of existing local material - dolomite aggregate.

\section{REFERENCES}

Bulevičius, M., Petkevičius, K., \& Čirba, S. (2013). The influence of geometric parameters on strength properties of the aggregates used to produce asphalt mixtures. Journal of Civil Engineering and Management, 19(6), 894-902. https://doi.org/10.3846/13923730.2013.858645

CEN/TS 15901-14:2016. Road and Airfield Surface Characteristics - Part 14: Procedure for Determining the Skid Resistance of a Pavement Surface Using a Device with Longitudinal Controlled Slip (LFCN): Viafriction (Road Analyser and Recorder of ViaTech AS).

Ciont, N., Iliescu, M., Błażejowski, K., \& Wójcik-Wiśniewska, M. (2017). Researching the Effects of Different Aggregates and Bitumen Types on Asphalt Mixtures. International Multidisciplinary Scientific GeoConference: SGEM: Surveying Geology \& Mining Ecology Management, 17(11), 487-494. https://doi.org/10.5593/sgem2017/11/S01.062

Cui, S., Blackman, B. R., Kinloch, A. J., \& Taylor, A. C. (2014). Durability of asphalt mixtures: Effect of aggregate type and adhesion promoters. International Journal of Adhesion and Adhesives, 54, 100-111. https://doi.org/10.1016/j.ijadhadh.2014.05.009

Descantes, Y., \& Hamard, E. (2015). Parameters influencing the polished stone value (PSV) of road surface aggregates. Construction and Building Materials, 100, 246-254. https://doi.org/10.1016/j.conbuildmat.2015.10.002

Gautam, P. K., Kalla, P., Jethoo, A. S., Agrawal, R., \& Singh, H. (2018). Sustainable use of waste in flexible pavement: a review. Construction and Building Materials, 180, 239-253. https://doi.org/10.1016/j.conbuildmat.2018.04.067 
Hall, J. W., Smith, K. L., Titus-Glover, L., Wambold, J. C., Yager, T. J., \& Rado, Z. (2009). Guide for Pavement Friction. Final Report for NCHRP Project 01-43. National Cooperative Highway Research Program (NCHRP). Transportation Research Board of the National Academies, Washington, DC. https://doi.org/10.17226/23038

Haritonovs, V., Tihonovs, J., \& Zaumanis, M. (2016). Performance evaluation of high modulus asphalt concrete mixes. In IOP Conference Series: Materials Science and Engineering (vol. 123, no. 1, pp. 012055). IOP Publishing. https://doi.org/10.1088/1757-899X/123/1/012055

Haritonovs, V., Zaumanis, M., Tihonovs, J., \& Smirnovs, J. (2013). Development of high performance asphalt concrete using low quality aggregates. In Proceedings of the 4th International Scientific Conference "Civil Engineering 13" (vol. 4). Latvia, Jelgava: Latvia University of Agriculture, 371 p. ISSN 2255-7776.

Kane, M., Scharnigg, K., Conter, M., Roe, P., \& Schwalbe, G. (2009). Report on different parameters influencing skid resistance, rolling resistance and noise emissions. TYROSAFE Deliverable $D, 10 \mathrm{p}$.

Kogbara, R. B., Masad, E. A., Kassem, E., Scarpas, A. T., \& Anupam, K. (2016). A state-of-the-art review of parameters influencing measurement and modeling of skid resistance of asphalt pavements. Construction and Building Materials, 114, 602-617. https://doi.org/10.1016/j.conbuildmat.2016.04.002

Lithuanian Road Administration under the Ministry of Transport and Communications (2019). TRA Aggregates 19 (in Lithuanian)

Lithuanian Road Administration under the Ministry of Transport and Communications (2008). TRA Asphalt 08 Technical Specifications for Road Asphalt Mixtures (in Lithuanian)

Lodhi, D. K. S., \& Yadav, R. K. (2016). Effect of gradation of aggregates on Marshall Properties of DBM Mix Design. International Journal of Engineering Research and Science \& Technology. ISSN 2319-5991.

https://doi.org/10.15623/ijret.2016.0502005

Noyce, D. A., Bahia, H. U., Yambo, J. M., \& Kim, G. (2005). Incorporating road safety into pavement management: maximising asphalt pavement surface friction for road safety improvements. Draft Literature Review and State Surveys, Midwest Regional University Transportation Center (UMTRI), Madison, Wisconsin.

Räisänen, M., Kupiainen, K., \& Tervahattu, H. (2003). The effect of mineralogy, texture and mechanical properties of anti-skid and asphalt aggregates on urban dust. Bulletin of Engineering Geology and the Environment, 62(4), 359-368. https://doi.org/10.1007/s10064-003-0200-y

Santucci, L., \& Engineer, L. F. (2013). Technology Transfer Program.

Scharnigg, K., \& Schwalbe, G. (2010). Tyrosafe (tyre and road surface optimisation for skid resistance and further effects). In International Surface Friction Conference, 3rd, 2011.

Siriphun, S., Chotisakul, S., \& Horpibulsuk, S. (2016). Skid resistance of asphalt concrete at the construction stage based on Thai aggregates. Journal of Materials in Civil Engineering, 28(12), 04016145.

https://doi.org/10.1061/(ASCE)MT.1943-5533.0001662
Lina Šneideraitienè, Daiva Žilioniené

Assessment of Skid Resistance of Road Pavements 
Šernas, O., Vorobjovas, V., Šneideraitienè, L., \& Vaitkus, A. (2016). Evaluation of asphalt mix with dolomite aggregates for wearing layer. Transportation Research Procedia, 14, 732-737. https://doi.org/10.1016/j.trpro.2016.05.340

Šneideraitienè, L., \& Žilionienė, D. (2019). Analysis and evaluation of the economic effect of asphalt mixtures AC 11 VS and SMA $11 \mathrm{~S}$ with different graded aggregates. Science - Future of Lithuania, 11. https://doi.org/10.3846/mla.2019.10588

Vaiana, R., Capiluppi, G. F., Gallelli, V., Iuele, T., \& Minani, V. (2012). Pavement surface performances evolution: an experimental application. Procedia-Social and Behavioral Sciences, 53, 1149-1160. https://doi. org/10.1016/j.sbspro.2012.09.964

Vaitkus, A., \& Vorobjovas, V. (2015). The use of dolomite crushed stone for asphalt topsoil mixtures. Lithuanian Roads, 1(34), 57-61. ISSN 1392-8678 (in Lithuanian)

Vaitkus, A., Andriejauskas, T., Šernas, O., Čygas, D., \& Laurinavičius, A. (2019). Definition of concrete and composite precast concrete pavements texture. Transport, 34(3), 404-414. https://doi.org/10.3846/transport.2019.10411

Vaitkus, A., Andriejauskas, T., Vorobjovas, V., Jagniatinskis, A., Fiks, B., \& Zofka, E. (2017a). Asphalt wearing course optimisation for road traffic noise reduction. Construction and Building Materials, 152, 345-356. https://doi.org/10.1016/j.conbuildmat.2017.06.130

Vaitkus, A., Vorobjovas, V., Kleizienė, R., Šernas, O., \& Gražulytė, J. (2017b). Modified asphalt mixtures for heavy duty pavement wearing layers. Construction and Building Materials, 131, 503-511. https://doi.org/10.1016/j.conbuildmat.2016.11.055

Vaitkus, A., Žilionienè, D., Paulauskaitè, S., Tuminienė, F., \& Žiliūtė, L. (2011). Research and assessment of asphalt layers bonding. Baltic Journal of Road \& Bridge Engineering, 6(3). https://doi.org/10.3846/bjrbe.2011.27

Vorobjovas, V., Šernas, O., Žilionienė, D., Šneideraitienė, L., \& Filotenkovas, V. (2017). Evaluation of high-quality dolomite aggregate for asphalt wearing course. In Environmental Engineering. Proceedings of the International Conference on Environmental Engineering, ICEE (vol. 10, pp. 1-6). Vilnius Gediminas Technical University, Dept of Construction Economics \& Property. https://doi.org/10.3846/enviro.2017.157

Wasilewska, M., Gardziejczyk, W., \& Gierasimiuk, P. (2019). Comparison of measurement methods used for evaluation the skid resistance of road pavements in Poland-case study. International Journal of Pavement Engineering, 1-7. https://doi.org/10.1080/10298436.2018.1562188

Wojcik, D. (2018). The New Oxford Handbook of Economic Geography. Oxford University Press.

Wu, Y., Parker, F., \& Kandhal, P. S. (1998). Aggregate toughness/abrasion resistance and durability/soundness tests related to asphalt concrete performance in pavements. Transportation Research Record, 1638(1), 85-93. https://doi.org/10.3141/1638-10 